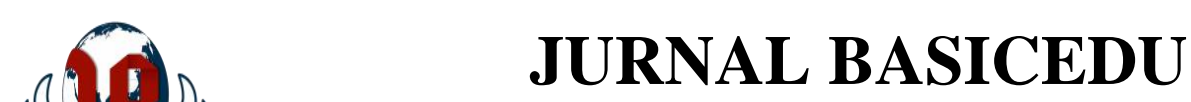

Volume 5 Nomor 4 Tahun 2021 Halaman 2133 - 2144

Research \& Learning in Elementary Education

https://jbasic.org/index.php/basicedu

\title{
Peningkatkan Motivasi dan Self Efficacy Belajar Matematika melalui Model Pembelajaran Berbasis Masalah pada Siswa Sekolah Dasar
}

\author{
Dyah Anungrat Herzamzam ${ }^{凶}$ \\ Program Studi Pendidikan Guru Sekolah Dasar, STKIP Kusuma Negara, Indonesia \\ E-mail: dyah@stkipkusumanegara.ac.id
}

\begin{abstract}
Abstrak
Penelitian ini bertujuan untuk meningkatkan motivasi dan self efficacy belajar matematika menggunakan pembelajaran berbasis masalah pada siswa kelas V SD N 5 bumirejo kecamatan kebumen. Penelitian ini adalah penelitian tindakan kelas (classroom action research) secara kolaboratif. Hasil penelitian menunjukkan bahwa model pembelajaran berbasis masalah dapat meningkatkan motivasi dan self efficacy belajar matematika pada siswa kelas V SD N 5 bumirejo kecamatan kebumen. Peningkatan motivasi dan self efficacy telah memenuhi kriteria keberhasilan. Hal itu ditunjukan dengan (1) Skor angket motivasi belajar siswa mengalami peningkatan dari sebelum tindakan sebesar 54,45\% dengan kategori rendah, siklus I sebesar 68,91\% dengan kategori sedang dan pada siklus II sebesar 83,34\% dengan kategori tinggi (2) Skor angket self efficacy belajar siswa mengalami peningkatan dari sebelum diberikan tindakan sebesar 49,94\% dengan kategori rendah, pada siklus I sebesar 69,20\% dengan kategori sedang dan pada siklus II sebesar 85,04\% dengan kategori tinggi.
\end{abstract}

Kata Kunci: Pembelajaran Berbasis Masalah, Motivasi, dan Self Efficacy

\begin{abstract}
This study aims to increase the motivation and self-efficacy of students learning mathematics using problembased learning approach in class V SD N V Bumirejo District Kebumen. This research is a classroom action research in a collaborative manner. The results show that the problem-based learning model can improve motivation and self-efficacy to learn mathematics of Class V students of Public Elementary School of Bumirejo 5 District Kebumen. Increased motivation and self-efficacy have met the criteria for success. It was shown that (1) The score of the students' motivation questionnaire has increased from before the action by 54,45\% with the low category. The first cycle was 68,91\% with a medium category and the second cycle amounted to 83,34\% with a high category (2) The score of students self-efficacy questionnaire has increased from before the given action 49,94\% with a low category, in the first cycle 69,20\% with a medium category and in the second cycle $85,04 \%$ with a high category.
\end{abstract}

Keywords: Problem Based Learning, Motivation and Self Efficacy

Copyright (c) 2021 Dyah Anungrat Herzamzam

Corresponding author :

Email : dyah@stkipkusumanegara.ac.id

DOI : https://doi.org/10.31004/basicedu.v5i4.1177

ISSN 2580-3735 (Media Cetak)

ISSN 2580-1147 (Media Online)

Jurnal Basicedu Vol 5 No 4 Tahun 2021

p-ISSN 2580-3735 e-ISSN 2580-1147 
2134 Peningkatkan Motivasi dan Self Efficacy Belajar Matematika melalui Model Pembelajaran Berbasis Masalah pada Siswa Sekolah Dasar - Dyah Anungrat Herzamzam

DOI: https://doi.org/10.31004/basicedu.v5i4.1177

\section{PENDAHULUAN}

Mata pelajaran matematika di sekolah sangat penting untuk melatih pola pikir siswa. Pola pikir siswa yang dimaksud adalah, berpikir logis, analitis, sistematis, kritis dengan penuh kecermatan. Pola pikir tersebut dapat diterima siswa apabila pembelajaran matematika di sekolah dikemas secara sistematis. Oleh karena itu, melalui belajar matematika, pola pikir siswa dapat dilatih. Mathematics is one of the subjects taught to every educational level, starting from primary education to the higher education, both general and vocational hal ini menurut (Farozin, Yudha, Herzamzam, \& Mungad, 2019) maknanya adalah dalam mempelajari matematika dibutuhkan kecermatan, karena materi dalam matematika berkelanjutan. Matematika merupakan ilmu penalaran logis serta dalam matematika terkait erat dengan masalah yang berkaitan dengan bilangan, ruang dan besaran. Salah satu cirinya adalah objek abstraknya. Namun, dalam sekolah, adalah mungkin untuk mendekati objek abstrak ini melalui hal-hal yang konkret.

Dalam mempelajari matematika diperlukan dorongan atau motivasi dari guru, orang tua, dan lingkungan siswa. Pada pembelajaran di kelas, motivasi siswa dapat dibentuk dengan bimbingan guru. Guru memberikan kemudahan belajar bagi siswa. Kemudahan dalam belajar matematika salah satunya dapat mengkaitkan pembelajaran matematika dengan permasalahan nyata yang sering dijumpai siswa dalam kehidupan sehari-hari. Oleh karena itu, dorongan dari motivasi guru sangat diperlukan, karena dalam belajar matematika sejatinya merupakan proses menemukan, dalam belajar matematika merupakan proses penemuan, menurut (Yudha, 2018a)

(Santrock, 2013) yang mendefinisikan motivation is defined as the process whereby goal-directed activities are instigated and sustained. Motivated actions include choice of tasks, effort (physical and mental), persistence, and achievement. Schunk mendefinisikan motivasi sebagai proses dimana kegiatan diarahkan untuk mencapai tujuan. Tindakan motivasi dapat dilihat dari cara memilih tugas, usaha yang dilakukan (fisik dan mental), ketekunan dan prestasi. Pendapat lain oleh (Mahmoud \& Tanni, 2014)"motivation is the driving force by which humans achieve their goals", maknanya motivasi adalah kekuatan pendorong di mana manusia mencapai tujuan mereka. Motivasi secara umum terbagi menjadi dua macam, yaitu motivasi intrinsik dan ekstrinsik. (Mahadi \& Jafari, 2012) menyebutkan bahwa "motivation, indeed, involves two main classifications as below: Intrinsic motivation and extrinsic motivation", yang maknanya yaitu motivasi dibagi menjadi dua jenis, motivasi intrinsik dan motivasi ekstrinsik. Motivasi intrinsik dapat dikatakan sebagai bentuk motivasi yang di dalamnya aktivitas belajar dimulai dan diteruskan berdasarkan suatu dorongan dari dalam diri dan secara mutlak terkait dengan aktivitas belajarnya. Motivasi ekstrinsik adalah dorongan seseorang untuk melakukan suatu tindakan dan tindakan yang dilaksanakan dengan tujuan ingin mendapatkan suatu penghargaan

Menurut (Yudha, 2018a) terdapat faktor-faktor yang mempengaruhi motivasi ekstrinsik adalah : (1) adanya reward. Rewardadalah pemberian penghargaan secara verbal mengenai kemampuan seseorang yang menguasai sesuatu. Serta adanya pengharapan dari kemampuan tersebut. (Froiland, Oros, Smith, \& Hirchert, 2012), "praise is the positive reinforcer that has the potential to elevate both intrinsic motivation and extrinsicmotivation", maknanya adalah pujian dapat meningkatkan kedua motivasi yaitu motivasi intrinsik dan ekstrinsik,(2) tekanan sosial. Tekanan Sosial adalah adanya tekanan dalam diri yang bersumber dari lingkungan seperti orang tua, teman dan lain sebagainya. Menurut (Rehman \& Haider, 2013) "teachers and parents role is important for motivating students", makna dari pendapat tersebut yaitu peran guru dan orang tua penting untuk memotivasi siswa, (3) hukuman. Hukuman adalah perlakuan tertentu yang sifatnya tidak mengenakkan atau menimbulkan penderitaan.Bentuk hukuman yang diberikan kepada siswa adalah hukuman yang bersifat mendidik seperti mencari artikel, mengarang dan lain sebagainya. Dapat disimpulkan bahwa faktor-faktor yang mempengaruhi motivasi ekstrinsik adalah reward, tekanan sosial, dan hukuman.

Upaya untuk membangkitkan motivasi belajar siswa menurut (Ambarningsih, 2014) yaitu: 1) menggunakan cara atau metode dan media mengajar yang bervariasi. Dengan metode dan media yang bervariasi 


\section{Peningkatkan Motivasi dan Self Efficacy Belajar Matematika melalui Model Pembelajaran Berbasis}

Masalah pada Siswa Sekolah Dasar - Dyah Anungrat Herzamzam

DOI: https://doi.org/10.31004/basicedu.v5i4.1177

kebosanan dapat dikurangi atau dihilangkan; 2) memilih bahan yang menarik minat dan dibutuhkan siswa; 3) memberikan sasaran atau tujuan pembelajaran; 4) memberikan kesempatan untuk sukses karena keberhasilan yang dicapai siswa dapat menimbulkan kepuasan kemudian membangkitkan motivasinya; 5) menciptakan suasana belajar yang kondusif sehingga menimbulkan motivasi belajar siswa; 6) mengadakan persaingan sehat dimana dalam persaingan tersebut dapat diberikan pujian, ganjaran, maupun hadiah

Pembelajaran yang dilaksanakan di kelas V SD N 5 Bumirejo Kebumen menekankan pada metode ekpositori. Guru hanya menerangkan materi dan contoh soal disertai tanya jawab. Pada saat proses pembelajaran siswa tidak hanya mendengar dan membuat catatan. Guru bersama siswa berlatih menyelesaikan soal latihan dan siswa bertanya apabila belum mengerti. Guru dapat memeriksa pekerjaan siswa secara individual, mengulang informasi yang belum jelas kepada siswa secara individual atau klasikal. Pada saat pelaksanaan pembelajaran sikap siswa pasif dalam mengutarakan pendapat saat pelajaran berlangsung, siswa bergurau dengan siswa lain dalam kelas, mengobrol dengan siswa lain yang tidak ada kaitannya dengan pelajaran, ditemukan beberapa siswa yang mengerjakan PR pelajaran lain, dan sebagian besar siswa tidak menyelesaikan tugas dan diskusi dari guru. Bila siswa diberi kesempatan untuk mempresentasikan jawaban di papan tulis, semua siswa diam dan cenderung tidak bersedia untuk menuliskan. Siswa lebih senang menunggu guru dalam menyelesaikan soal tersebut. Hasil yang diperoleh selama ini, sebagian besar siswa memiliki motivasi rendah dalam mengikuti pembelajaran matematika. Sebagian kecil siswa termotivasi dalam menjawab pertanyaan dari guru dan mengajukan pertanyaan pada guru.

Dari observasi yang dilaksanakan diperoleh data rendahnya motivasi belajar siswa, hal ini terlihat dari 9 siswa yang bergurau, berbicara dengan teman, tidak menyelesaikan tugas ketika pembelajaran matematika berlangsung. Sebanyak 25 siswa pasif saat diberikan kesempatan untuk menuliskan jawaban di papan tulis tanpa dorongan guru. Siswa diam atau tanpa suara ketika diberikan kesempatan untuk menuliskan jawaban dari latihan soal. Ketika diberikan dorongan oleh guru dalam menuliskan jawaban di papan tulis, hanya 3 siswa yang bersedia mempresentasikan. Sebanyak 22 siswa pasif saat ditanya pendapatnya maupun saat diberikan kesempatan untuk bertanya mengenai materi pelajaran yang berlangsung. 16 siswa duduk, memperhatikan, mendengarkan guru dengan seksama, dan pandangan mata tertuju pada papan tulis..

Berdasarkan wawancara terhadap semua siswa kelas 5 SD Negeri 5 Bumirejo, terlihat bahwa sebagian besar siswa memiliki self efficacy yang rendah, terlihat dari banyak siswa yang mencontek saat ulangan, siswa tidak yakin dengan jawaban mereka sendiri, siswa ragu ketika menuliskan jawaban di depan kelas. Siswa tidak yakin dalam belajar matematika karena matematika tidak menarik dan terkesan monoton. Siswa menganggap bahwa pembelajaran yang dilaksanakan guru melalui pemberian soal, tanya jawab, dan menjelaskan materi yang sebagian besar siswa tidak mampu menyelesaikan. Kondisi ini sangat menghambat transfer pembelajaran khususnya mata pelajaran matematika. Hal ini menyebabkan siswa hanya dapat memahami pelajaran tanpa mengetahui implementasi dalam kehidupan sehari-hari. Oleh karena itu, dalam proses pembelajaran di kelas diperlukan variasi dalam guru mentransfer pengetahuan matematika pada siswa yang mengkaitkan pada permasalahan sehari-hari.

Menurut (Santrock, 2012) "Self efficacy is the belief that one can master a situation and produce favorable outcomes", maknanya adalah Self efficacy merupakan keyakinan bahwa seseorang dapat menguasai sebuah situasi dan memberikan hasil yang menguntungkan. Situasi yang menguntungkan timbul apabila terdapat dorongan dan kemampuan untuk mencapainya. Konsep self efficacy memasukkan 3 aspek yaitu Level, Strength, Generality.Menurut (Acuña et al., 2011) self efficacy terdiri dari tiga aspek, yaitu level, strength, generality, adapun secara rinci dijelaskan sebagi berikut: (1) Level(Besaran) Yaitu tingkat kesulitan situasi atau tugas yang dihadapi. Ini mengacu pada kesederhanaan atau kekompleksan tugas yang individu rasa mampu untuk melakukannya. Jika dihadapkan pada tugas-tugas yang disusun menurut tingkat kesulitan, maka individu akan memilih tugas-tugas yang mudah, sedang atau sulit sesuai dengan batas kemampuan yang dirasakan bisa untuk menyelesaikan tugas-tugas tersebut dengan baik. (2) Generality (luas bidang) Yaitu rentang atau luas 


\section{Peningkatkan Motivasi dan Self Efficacy Belajar Matematika melalui Model Pembelajaran Berbasis}

Masalah pada Siswa Sekolah Dasar - Dyah Anungrat Herzamzam

DOI: https://doi.org/10.31004/basicedu.v5i4.1177

bidang tugas yang mana individu rasa dapat menyelesaikannya. Dimensi ini menemukan bahwa self efficacy seseorang itu tidak hanya terbatas pada situasi yang spesifik saja,tapi berhubungan dengan luas bidang tingkah laku. Beberapa individu merasa mampu menangani atau melakukan tugas-tugas dalam bidang yang luas,sementara beberapa individu mungkin merasa hanya bisa pada area atau bidang spesifik atau tertentu saja. (3) Strength(kekuatan) Yaitu tingkat keyakinan atau kemantapan individu bahwa ia merasa mampu menyelesaikan tugasnya dengan baik dan sempurna. Individu dengan self efficacy yang lemah lebih mudah menyerah pada pengalaman-pengalaman ketidakberhasilan, sementara individu yang mempunyai self efficacy yang kuat akan tetap berusaha, meskipun menemui pengalaman yang tidak mengenakkan atau menghambat. Menurut (Santrock, 2013) terdapat tujuh strategi untuk meningkatkan self efficacy, antara lain: (1) Mengajarkan strategi spesifik, (2) Membimbing siswa dalam menentukan tujuan, (3) Mempertimbangkan mastery, (4) Mengkombinasikan strategi training dengan tujuan, (5) Menyediakan dukungan bagi siswa, (6) Memastikan agar siswa untuk tidak terlalu semangat atau cemas. (6) Menyediakan model yang bersifat positif dari orang dewasa dan teman (modeling).

Usaha yang selama ini dilakukan guru dalam mengatasi rendahnya motivasi dan kemampuan (self efficacy) matematika siswa adalah dengan penghafalan materi dan prosedur. Penghafalan dan prosedur dalam matematika melalui pemberian soal dan pembimbingan dalam mencari hasil jawaban. Siswa telah terbiasa dalam proses pembelajaran yang prosedural, siswa menerima materi yang diberikan guru tanpa mempunyai inisiatif mencari dan menemukan sendiri pengetahuan dan ketrampilan yang mereka butuhkan. Selain itu, guru hanya memberikan tugas dan pekerjaan rumah pada siswa setiap hari. Hal ini,diberikan agar siswa setiap hari belajar matematika. Berdasarkan permasalahan di atas, maka upaya meningkatkan motivasi dan self efficacy siwa sangat diperlukan.

Solusi untuk mengatasi rendahnya motivasi dan self efficacy menggunakan pembelajaran berbasis masalah. Model PBM merupakan model pembelajaran yang lebih menekankan pada pemecahan masalah atau masalah sebagai titik tolak. Siswa dapat mengembangkan dan menumbuhkan keterampilan menyelesaikan masalah, siswa bertindak sebagai pemecah masalah dan dalam pembelajaran dibangun proses berpikir, kerja kelompok, berkomunikasi dan membagi informasi. PBM menyajikan kepada siswa situasi masalah yang otentik dan bermakna yang dapat memberikan kemudahan kepada siswa untuk melakukan penyelidikan terhadap pengetahuan yang sedang diperolehnya. Oleh karena itu, model pembelajaran PBM sangat diperlukan oleh siswa dalam proses belajar matematika.

Proses pembelajaran PBM dimulai dengan permasalahan.Menurut (Anik Handayani \& Koeswanti, 2021) masalah yang disajikan adalah masalah yang memiliki konteks dengan dunia nyata. Semakin dekat dengan dunia nyata, akan semakin baik pada pengaruhnya pada peningkatan kecakapan siswa. Dari masalah yang diberikan ini, siswa bekerja sama dalam berkelompok, mencoba memecahkannya dengan pengetahuan yang mereka miliki, dan sekaligus mencari informasi- informasi baru yang relevan untuk solusinya. Senada dengan pendapat tersebut, (Yudha, 2018b) menyebutkan bahwa proses pembelajaran berbasis masalah selalu dimulai dari penyajian masalah sebagai awal pembelajaran, dan masalah selalu disajikan selalu bersifat kontekstual dengan dunia realita siswa. Masalah yang digunakan sebagai stimulus belajar diorganisasikan sedemikian rupa sehingga dapat memunculkan konsep- konsep, prinsip- prinsip, serta kaidah kaidah yang relevan dengan materi yang dibahas. Konsep, prinsip, atau kaidah- kaidah yang diperlukan untuk pemecahan masalah digali oleh siswa melalui proses belajar secara mandiri (self directed learning). Dengan demikian melalui proses PBM tersebut siswa diharapkan lebih termotivasi dalam belajar matematika dan melalui motivasi, siswa dapat memperoleh kemampuan dalam belajar matematika di kelas.

Tahapan pembelajaran dengan model pembelajaran berbasis masalah yang digunakan dalam penelitian ini mengadopsi dari Langkah PBM Menurut (Arends, 2012) Langkah pertama: mengorientasi masalah dan pemberian masalah berkaitan dengan materi; 2) Langkah kedua: mengorganisasikan siswa secara berkelompok untuk meneliti melalui penyelidikan; 3) Langkah ketiga: membantu penyelidikan mandiri dan kelompok; 4) 


\section{Peningkatkan Motivasi dan Self Efficacy Belajar Matematika melalui Model Pembelajaran Berbasis}

Masalah pada Siswa Sekolah Dasar - Dyah Anungrat Herzamzam

DOI: https://doi.org/10.31004/basicedu.v5i4.1177

Langkah keempat: mempresentasikan hasil dari penyelidikan; 5) Langkah kelima: menganalisis dan mengevalusi hasil penyelidikan.

Model PBM efektif untuk diterapkan di kelas V SD N 5 Bumirejo Kebumen, PBM efektif diterapkan dikarenakan dalam sekolah ini tidak adanya inofasi proses belajar, karena tidak adanya inovasi dalam proses belajar menyebabkan siswa menjadi tidak termotivasi dan mendapatkan hasil yang tidak optimal. PBM diterapkan dengan pertimbangan bahwa siswa mendapatkan pengetahuan dasar yang berguna untuk memecahkan masalah-masalah yang dijumpainya, berpusat pada siswa dimana siswa secara aktif dan mandiri dengan sajian materi kontekstual dan relevan. Guru bukan lagi sebagai sumber utama pengetahuan namun sebagai fasilitator. Pembelajaran menjadi bermakna, bukan lagi menghafal tetapi menggunakan informasi untuk memecahkan masalah- masalah dalam kehidupan nyata.Penyelesaian masalah nyata melalui mengerjakan secara individu atau diskusi secara kelompok.

Dari permasalahan diatas diperolah rumusan masalah bagaimana meningkatkan motivasi dan self efficacy belajar matematika siswa kelas V SD Negeri 5 Bumirejo melalui pembelajaran berbasis masalah?. Tujuan penelitian adalah untuk meningkatkan motivasi belajar siswa dan self efficacy belajar matematika siswa melalui model pembelajaran berbasis masalah pada siswa kelas V SD N 5 Bumirejo kebumen kecamatan kebumen. Manfaat dari penelitian ini adalah siswa memiliki motivasi dan self efficacy terhadap mata pelajaran matematika. Selain itu bagi guru dalam memilih alternatif model pembelajaran yang dapat meningkatkan partisipasi belajar dan serta meningkatkan pemahaman siswa dalam pembelajaran.

\section{METODE}

Jenis Penelitian dalam penelitian ini adalah penelitian tindakan kelas (classroom action research). Tempat Penelitian ini dilaksanakan di kelas V SD Negeri 5 Bumirejo Kebumen Kecamatan Kebumen. Dari enam kelas yang ada,kelas lima adalah kelas yang relatif bermasalah dibandingkan dengan kelas lain. Untuk itu kelas tersebut dipilih sebagai subjek penelitian. Subjek Penelitian ini adalah semua siswa kelas V SD Negeri 5 Bumirejo Kebumen Kecamatan Kebumen sebanyak 35 orang dengan jumlah siswa laki- laki 14 siswa dan siswa perempuan 21 siswa yang sebagian besar memiliki motivasi dan self efficacy belajar matematika yang rendah. Prosedur tindakan yang diterapkan dalam penelitian tindakan kelas ini, mengacu pada empat aspek pokok model (Kemmis, McTaggart, \& Nixon, 2014) yaitu perencanaan, pelaksanaan, observasi, dan refleksi. Adapun Keempat aspek model Kemmis dan Mc Taggart melalui tahapan sebagai berikut:

Tahapan tindakan pada penelitian iini yaitu Perencanaan penelitian, Pada tahap ini peneliti menentukan fokus peristiwa yang dianggap perlu untuk diamati secara mendalam. Selanjutnya merencanakan perencanaan meliputi: (1) Membuat Rencana Pembelajaran (RPP). Penyusunan RPP dengan bimbingan validator dan dosen pembimbing. RPP yang digunakan telah divalidasi oleh validator. Adapun materi yang disajikan yaitu dengan materi sifat-sifat bangun dan hubungan antarbangun. (2) Mengembangkan instrumen observasi pembelajaran berbasis masalah dan angket self efficacy, angket motivasi belajar siswa dan lembar kerja siswa kelompok (LKSK) yang telah divalidasi oleh validator. (3) Menyiapkan media atau alat peraga yang dibutuhkan. (4) Menentukan kelas penelitian adalah kelas V SD Negeri 5 Bumirejo kebumen Kecamatan Kebumen. (5) Waktu penelitian adalah semester II, (6) Menyampaikan pengarahan dan latihan menggunakan model pembelajaran berbasis masalah kepada guru kelas sebagai praktisi agar dalam melaksanakan tindakan sesuai dengan RPP yang telah dirancang. (7) Membuat jadwal penelitian bersama-sama dengan guru kelas V. (8) Guru membentuk kelompok kecil yang terdiri 5 orang dari setiap kelompok dan mempertimbangkan perbedaan jenis kelamin dan kemampuan akademis siswa. Tindakan dalam penelitian ini dilakukan dalam dua siklus. Tahap pelaksanaan mengikuti skenario yang telah dirancang. Hal ini meliputi kegiatan awal, kegiatan inti, dan kegiatan penutup. Pelaksanaan tindakan dilakukan oleh guru kelas V dengan menggunakan pendekatan PBM. Pada pelaksanaan mencakup langkah-langkah (sintaks) tindakan pembelajaran matematika menggunakan PBM. Adapun langkah tindakannya: 1) Langkah pertama: mengorientasi masalah dan pemberian masalah berkaitan dengan materi; 2) 
Langkah kedua: mengorganisasikan siswa secara berkelompok untuk meneliti melalui penyelidikan; 3) Langkah ketiga: membantu penyelidikan mandiri dan kelompok; 4) Langkah keempat: mempresentasikan hasil dari penyelidikan; 5) Langkah kelima: menganalisis dan mengevalusi hasil penyelidikan. Pada tahap observasi, dilaksanakan oleh peneliti dan kolaborator secara berkelanjutan saat pembelajaran berlangsung. Tahap ini dilaksanakan dalam waktu yang bersamaan dengan tahap pelaksanaan tindakan. Pada tahap ini mengamati proses pembelajaran menggunakan lembar observasi guru dan siswa. Pengamatan dilakukan oleh peneliti dibantu oleh kolaborator. Hal ini, agar guru dapat menjalankan proses pembelajaran menggunakan pendekatan PBM dengan maksimal. Angket digunakan untuk mengukur motivasi siswa dan self efficacy diberikan kepada siswa setiap akhir siklus. Tahap Refleksi Pada penelitian ini dilaksanakan pada akhir siklus pertama. Tahap refleksi digunakan untuk mengevaluasi proses dan hasil tindakan oleh peneliti, guru dan observer. Hasil tindakan dianalisis untuk dilihat target pencapaiannya. Apabila pembelajaran yang telah dilaksanakan telah memenuhi kriteria keberhasilan maka tindakan dihentikan. Apabila tidak mencapai target yang diharapkan, maka dilaksanakan perbaikan untuk dilaksanakan pada siklus berikutnya.

Pada penelitian ini dilanjutkan pada Siklus kedua Siklus dua dilaksanakan karena pembelajaran pada siklus pertama dinilai belum berhasil mencapai ketuntasan belajar dan proses belajar siswa.. Langkah-langkah yang dilakukan dalam siklus dua pada dasarnya sama dengan siklus pertama, akan tetapi pada siklus dua dilakukan perbaikan terhadap kekuarangan pada siklus pertama. Jika pada siklus dua hasil observasi dan refleksi menunjukkan peningkatan pelaksanaan pembelajaran yang tercermin dari kriteria ketercapaian maka penelitian di hentikan sampai pada siklus dua dan tidak dilanjutkan pada siklus berikutnya.

Teknik pengumpulan data yang digunakan dalam penelitian ini adalah observasi dan angket. Teknik ini digunakan karena dipandang lebih efektif untuk mendapatkan data sebanyak-banyaknya. Validitas yang digunakan dalam penelitian ini adalah validitas isi (content validity). Validitas isi instrumen mengacu pada sejauh mana item instrumen mencangkup keseluruhan situasi yang ingin diukur. (Idrus L, 2019) bahwa agar memenuhi validitas isi, dapat pula dimintakan bantuan ahli bidang studi. Validitas instrument yang digunakan dalam penelitian ini adalah validitas isi (content validity) untuk instrument angket dan observasi. Lembar observasi dan angket diketahui dari kesesuaian instrument yang telah dikembangkan dengan kisi-kisinya. Penyusunannya berdasarkan arahan dari dosen pembimbing serta instrument tersebut divalidasi oleh dosen ahli (expert judgement), semua instrument direvisi mengikuti saran dan arahan dari dosen ahli tersebut.

Instrumen pengumpulan data dalam penelitian ini yaitu (1) Rating Scale Lembar observasi digunakan sebagai pedoman untuk melakukan observasi atau pengamatan guna memperoleh data yang diinginkan. Lembar observasi digunakan untuk mengamati kegiatan pembelajaran dengan menerapkan model pembelajaran berbasis masalah. Pernyataan dalam lembar observasi ini mempunyai dua alternatif jawaban, yaitu ya atau tidak serta dipertegas melalui keterangan. Observasi dalam penelitian ini dengan cara melakukan pengamatan langsung dan pencatatan mengenai pelaksanaan guru dalam menerapkan pembelajaran matematika di kelas. (2) Lembar Angket tertutup Angket penelitian ini menggunakan angket tertutup dalam bentuk skala sikap dari Likert. Angket berisi item-item instrumen yang berupa pernyataan dan perskoran menggunakan empat alternatif jawaban untuk setiap pernyataan. Angket digunakan untuk mengukur motivasi siswa dan self efficacy diberikan kepada siswa setiap akhir siklus. Indikator-indikator yang digunakan dalam angket motivasi belajar matematika diambil dari Woolkfolk.

Untuk menentukan berhasil atau tidaknya penelitian dibutuhkan indikator keberhasilan. Indikator dalam penelitian ini meliputi. (a) Dari segi motivasi, dikatakan berhasil apabila minimal 75\% siswa kelas V SD Negeri 5 Bumirejo dalam kategori tinggi yang dapat dilihat dari kategori presentase skor motivasi belajar matematika siswa. (bDari segi self efficacy, dikatakan berhasil apabila minimal 75\% siswa kelas V SD Negeri 5 Bumirejo dalam kategori tinggi yang dapat dilihat dari kategori presentase skor self efficacy belajar matematika siswa. 
2139 Peningkatkan Motivasi dan Self Efficacy Belajar Matematika melalui Model Pembelajaran Berbasis Masalah pada Siswa Sekolah Dasar - Dyah Anungrat Herzamzam

DOI: https://doi.org/10.31004/basicedu.v5i4.1177

\section{HASIL DAN PEMBAHASAN}

Dari penelitian yang telah dilaksanakan, diperoleh hasil penelitian tentang motivasi dan self eficacy belajar matematika siswa di SD N Bumikrejo 5 Kebumen, adapun hasil penelitian yang diperoleh antara lain: Peningkatan motivasi belajar siswa dan self efficacy.

Berdasarkan hasil analisis data dari pengisisan kuisioner angket, terlihat peningkatan motivasi belajar siswa yaitu pada sebelum tindakan rata-rata kelas sebesar 54,45\% dengan kategori rendah, meningkat menjadi 68,91\% dengan kategori sedang pada , dan pada I meningkat kembali menjadi 84,34\% dengan kategori tinggi. Pada kondisi awal guru mengajar lebih banyak menggunakan metode ceramah. Guru lebih banyak memberikan cara pengerjaan soal dan langkah-langkah di tulis di papan tulis,sehingga siswa memahami konsep secara mandiri. Hal tersebut dimungkinkan dapat menurunkan motivasi siswa. Siswa berbicara dengan teman sebangkunya, tidak menyelesaikan tugas yang diberikan guru. Pada ni peningkatan motivasi siswa diupayakan melalui kegitan belajar kelompok dan pemberian masalah. Beberapa hal tersebut menyebabkan siswa aktif dalam usaha menguasai materi pembelajaran dengan didukung suasana kelas yang terasa lebih menyenangkan untuk belajar matematika

Motivasi belajar telah meningkat, hal ini terbukti siswa merasa sangat bersemangat ketika mengikuti kegiatan pembelajaran. Siswa merasa ingin menyelesaikan semua masalah-masalah yang diberikan oleh guru. Siswa berlomba-lomba untuk menjawab setiap masalah yang terdapat pada LKSK secara berkelompok. Setiap kelompok mempunyai perwakilan untuk menyampaikan hasil diskusinya. Bagi siswa yang mampu mempresentasikan hasil jawabanya akan mendapatkan penghargaan dari guru serta diberikan pujian berupa tepuk tangan.

Kelompok yang mendapatkan penghargaan oleh guru pada siklus 1 lebih termotivasi pada penyelesaian masalah siklus II. Pada kegiatan pembelajaran siklus II, terdapat beberapa perubahan. Perubahan tersebut misalnya masalah yang diberikan pada LKSK lebih menarik yaitu terdapat kegiatan dimana siswa diberikan kesempatan untuk menggambar, menggunting, dan mengelem. Selain itu kelompok yang mempresentasikan hasilnya di depan kelas diwakilkan oleh seluruh anggota kelompok tersebut. Bagi kelompok yang mempresentasikan hasilnya akan mendapatkan penghargaan dan diberikan pujian berupa tepuk tangan selain itu akan diberikan point plus. Dengan demikian melalui perubahan ini motivasi belajar siswa semakin meningkat.

Pada awal siklus, ada beberapa siswa yang belum terbiasa dengan belajar matematika secara berkelompok, terlebih dalam belajar harus saling kerja sama. Namun, motivasi siswa secara perlahan mulai nampak. Dari beberapa kegiatan diatas dapat disimpulkan bahwa peningkatan motivasi belajar terjadi dikarenakan siswa mampu mengikuti serangkaian tahapan-tahapan pembelajaran berbasis masalah.

Tabel 1

Persentase Motivasi Belajar siswa Sebelum Tindakan, Siklus I, dan II

\begin{tabular}{cccc}
\hline $\begin{array}{c}\text { Motivasi } \\
\text { Belajar }\end{array}$ & $\begin{array}{c}\text { Sebelum } \\
\text { Tindakan }\end{array}$ & Siklus I & Siklus II \\
\hline
\end{tabular}

\begin{tabular}{llll}
\hline Persentase & $54,45 \%$ & $68,91 \%$ & $84,34 \%$ \\
\hline
\end{tabular}

Rata-rata angket motivasi siswa sebelum diberikan tindakan adalah 54,45\% dengan kategori rendah, pada rata-rata tersebut mengalami kenaikan pada siklus I menjadi 68,91\% dengan kategori sedang dan akhir pertemuan yaitu pada siklus II rata-rata angket motivasi belajar siswa meningkat yaitu 84,34\% dengan kategori tinggi. Pada siklus II persentase motivasi belajar siswa dalam kategori tinggi. Kategori tersebut telah mencapai kriteria keberhasilan tindakan yang ditentukan oleh peneliti, sehingga peneliti memutuskan untuk mengehentikan penelitian. Pembandingan rata-rata persentase skor angket motivasi belajar sebelum tindakan,siklus I, dan siklus II disajikan pada gambar 3. 


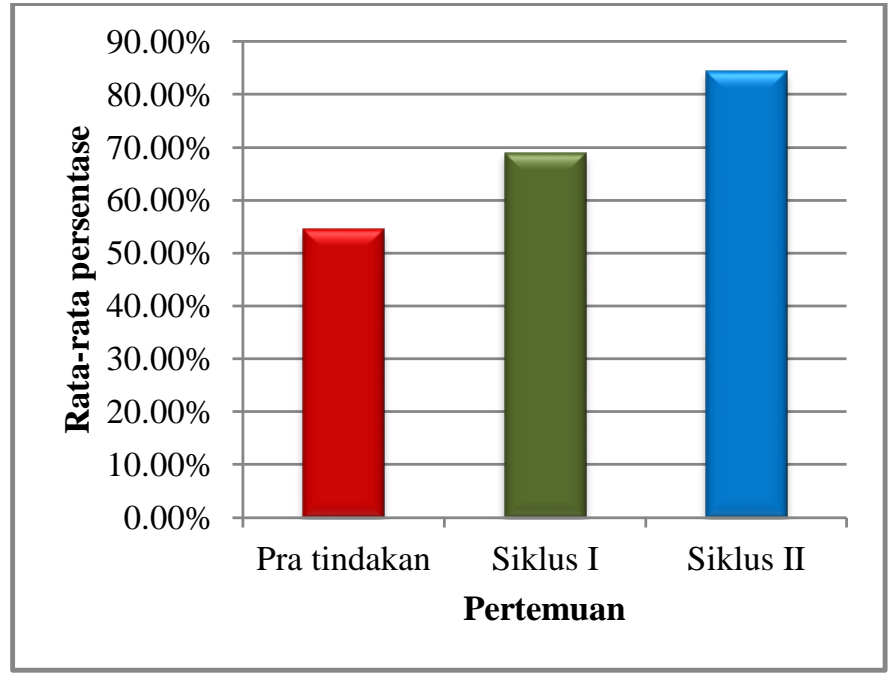

Gambar 1. Pembandingan rata-rata persentase skor angket motivasi belajar sebelum tindakan, siklus I, dan siklus II

Motivasi belajar siswa mengalami peningkatan. Hal tersebut terdapat hubungan motivasi belajar dengan PBM. Bahwa, dalam PBM diberikan beberapa langkah untuk meningkatkan motivasi siswa, diantaranya sebagai berikut. (a). Pemberikan Orientasi Masalah, Pada tahap ini siswa lebih termotivasi dalam menyelesaikannya, apabila dalam segi akademis siswa tersebut kurang baik, maka melalui tahapan ini dapat diperbaiki. Sesuai dengan penelitian, sebagian besar siswa merasa senang belajar matematika menggunakan benda nyata dan memiliki rasa ingin tahu yang tinggi. hal ini sesuai dengan pendapat (Sardiman 2011, p.75). Motivasi belajar merupakan faktor psikis yang bersifat non intelektual. Peranannya yang khas adalah dalam hal penumbuhan gairah, merasa senang, dan semangat untuk belajar. Karakteristik PBM yang muncul pada tahap ini menurut menurut (Dewi, Wiyasa, \& Suniasih, 2020) adalah masalah yang digunakan sebagai awal pembelajaran dan masalah yang digunakan merupakan masalah dunia nyata yang disajikan secara mengambang (ill-stuctured). (b). Pengorganisasian siswa untuk belajar, pada tahapan ini, guru membagi siswa dalam kelompok. Pada tahap ini guru membimbing semua siswa tentang pentingnya kerja sama antar anggota kelompok dalam menyelesaikan masalah. Guru mendorong siswa untuk bekerja sama dalam tim saat belajar bersama atau menyekesaikan masakah. Masalah yang dimaksud adalah tertuang pada LKSK. Menurut Menurut (Woolfolk 2009, p.227) motivasi ekstrinsik muncul salah satunya pada Tekanan Sosial. Tekanan sosial adalah adanya tekanan dalam diri yang bersumber dari lingkungan seperti orang tua, teman dan lain sebagainya. Oleh karena itu diperoleh bahwa, sebagian besar siswa berminat dalam mengerjakan dan menyelesaikan LKSK. (c). Penyelidikan mandiri atau kelompok, guru membimbing siswa dalam mengerjakan dan memperoleh tujuan yang ingin dipecahkan yang tertuang dalam LKSK. Guru membimbing siswa menyelesaikan masalah sesuai dengan langkah-langkah yang terdapat dalam LKSK. Guru membimbing siswa untuk menyelesaikan pertanyaan yang mengarah pada jawaban yang benar sesuai dengan konsep matematika yang sedang dipelajari. Siswa dalam kelompok memiliki tugas masing-masing dan diolah agar semua siswa mampu mencoba peran secara bergantian. Terdapat siswa yang tugasnya menuliskan jawaban, adapula yang bertugas mencari informasi sebanyak-banyaknya dalam memecahkan masalah, walaupun jawaban dari masing-masing siswa berbeda. Sebagian besar siswa dalam tahap ini merasa gembira dan tekun dalam mengerjakan LKSK. Selain itu sebagaian besar siswa merasa bahwa, agar tujuan untuk memperoleh penyelesaian dari masing-masing pertanyaan yang tertuang dalam LKSK diselesaikan secara maksimal, maka pada tahap ini sesuai dengan (Santrock, 2012) bahwa makin sanggup orang memenuhi kebutuhan mereka untuk mengetahui dan memahami dunia di sekeliling mereka, motivasi mereka mungkin akan menjadi lebih besar untuk mempelajari lebih banyak lagi. (d).Mempresentasikan hasil karya, guru mendorong siswa untuk mampu berinteraksi dalam diskusi 
kelompok atau dengan guru, dan memberikan penjelasan terhadap penyelesaian jawabannya di depan kelas yang didasari alasan yang jelas atas temuan konsep dan prinsip matematika yang diperoleh. Guru mendorong siswa untuk aktif berdiskusi dengan siswa, mendorong siswa untuk mempresentasikan penyelesaian masalah di depan kelas, dan mondorong memberikan pendapat apabila terdapat perbedaan jawaban LKSK. Apabila terdapat jawaban siswa yang tidak tepat, maka guru memberikan gambaran tentang arahan jawaban yang tepat. Apabila terdapat jawaban yang tepat, maka bersama-sama siswa memberikan pengargaan melalui tepuk tangan. Pada tahapan ini sebagian besar siswa merasa puas dengan jawaban yang telah dipresentasikan di depan kelas, walaupun ada sebagain kecil siswa yang belum mampu mengerjakan secara tepat. Hal ini sesuai dengan pendapat (Areepattamannil, Freeman, \& Klinger, 2011) yang menyebutkan bahwa "Intrinsic motivation to accomplish, on the other hand, refers to the desire to perform an activity for the pleasure and satisfaction that one receives from accomplishing or creating new things". (e).Menganalisis dan mengevaluasi pemecahan masalah. Dari hasil diskusi kelas, guru mengarahkan siswa untuk menarik kesimpulan tentang konsep atau definisi, teorema, prinsip atau prosedur matematika yang terkait dengan masalah yang baru diselesaikan. Dengan demikian sebagian besar siswa mengetahui, dari penyelesaian masalah yang ditemukan, apakah telah menjawab tujuan atau belum. Hal ini sesuai dengan pendapat oleh (Froiland et al., 2012) Motivation is the desire and energy that moves you to complete a task or reach a goal, maknanya adalah motivasi adalah keinginan dan tenaga yang menggerakan seseorang untuk menyelesaikan tugas atau mencapai tujuan.

Selain motivasi bejar, terdapat Peningkatan self efficacy Berdasarkan hasil analisis data dari pengisisan kuisioner angket, terlihat peningkatan self efficacy belajar siswa yaitu pada sebelum tindakan rata-rata kelas sebesar 49,94\% dengan kategori rendah, meningkat menjadi 69,2\% dengan kategori sedang pada siklus I, dan pada siklus II meningkat kembali menjadi $85,04 \%$ dengan kategori sangat tinggi. Pada kondisi awal guru menerangkan materi dan contoh soal disertai tanya jawab, mengajar lebih banyak menggunakan metode ceramah dan tanya jawab. Hal tersebut dimungkinkan dapat menurunkan self efficacy siswa. Siswa pasif dalam mengutarakan pendapat saat pelajaran berlangsung, siswa tidak bersedia mempresentasikan hasil jawaban di depan kelas, banyak siswa yang mencontek saat ulangan, siswa tidak yakin dengan jawaban mereka sendiri. Peningkatan self efficacy siswa diupayakan melalui kegitan belajar kelompok dan pemberian masalah. Beberapa hal tersebut menyebabkan siswa untuk aktif dalam usaha menguasai materi pembelajaran dengan didukung suasana kelas yang terasa lebih menyenangkan untuk belajar matematika.

Peningkatan self efficacy belajar telah terwujud, dikarenakan siswa merasa sangat yakin dengan kemampuan yang dimiliki, tidak malu untuk bertanya tentang materi LKSK yang belum dipahami, berani menjawab pertnyaan dari guru, berani untuk mempresentasikan hasil diskusi kelompok. Setiap kelompok mempunyai perwakilan untuk menyampaikan hasil diskusinya. Bagi siswa yang mampu mempresentasikan hasil jawabannya akan mendapatkan penghargaan dari guru serta diberikan pujian berupa tepuk tangan.

Kelompok pada siklus 1 yang telah mendapat predikat kelompok/tim yang hebat akan semakin yakin dengan kemampuan mereka dalam menyelesaikan masalah-lmasalah yang terdapat pada LKSK di siklus II. Pada kegiatan pembelajaran pada siklus II, terdapat beberapa perubahan. Perubahan tersebut misalnya masalah yang diberikan pada LKSK lebih menarik yaitu terdapat kegiatan dimana siswa diberi kesempatan untuk menggambar, menggunting, dan mengelem. Selain itu kelompok yang maju di depan kelas diwakilkan oleh seluruh anggota kelompok tersebut. Bagi kelompok yang maju akan mendapatkan hadiah dan akan diberikan pujian berupa tepuk tangan selain itu akan diberikan nilai tambahan. Dengan demikian adanya perubahan ini diharapkan self efficacy belajar siswa semakin meningkat.

Tabel 2

Persentase Self Eficacy Belajar siswa Sebelum Tindakan, Siklus I dan II

Self Sebelum

eficacy Tindakan Siklus I Siklus II

\begin{tabular}{llll} 
Persentase & $49,94 \%$ & $69,2 \%$ & $85,04 \%$ \\
\hline
\end{tabular}


2142 Peningkatkan Motivasi dan Self Efficacy Belajar Matematika melalui Model Pembelajaran Berbasis Masalah pada Siswa Sekolah Dasar - Dyah Anungrat Herzamzam

DOI: https://doi.org/10.31004/basicedu.v5i4.1177

Adapun Grafik Pembandingan rata-rata persentase Self Eficacy Belajar siswa Sebelum Tindakan, dan II dalam pembelajaran melalui PBM disajikan pada gambar berikut ini:

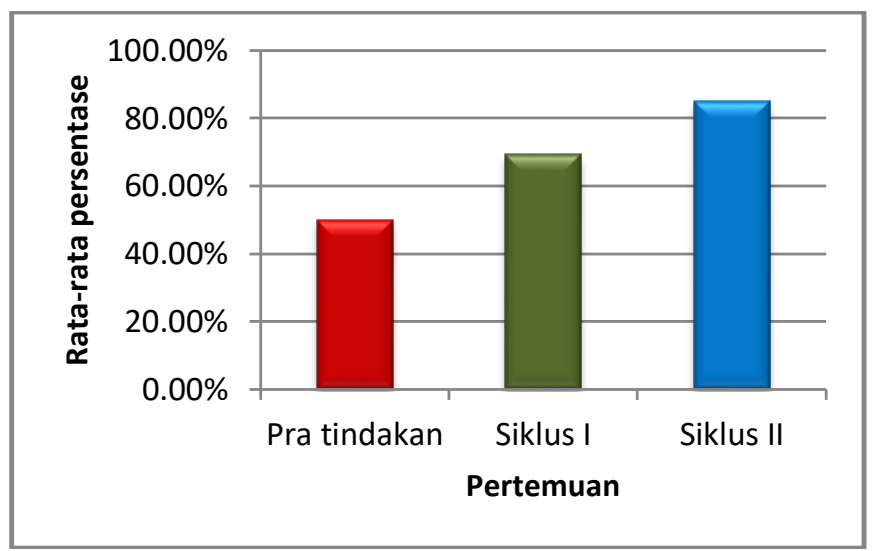

\section{Gambar 2. Pembandingan Rata-rata Persentase Angket Self Efficacy Belajar Sebelum Tindakan, Siklus I dan II}

Hasil ini menunjukkan bahwa self efficacy siswa mengalami peningkatan di setiap siklus. Peningkatan tersebut dikarenakan melalui penerapan pembelajaran yang tepat, pembelajaran yang diterapkan yaitu PBM (Flammer, 2018). Menurut (Ali, Hukamdad, Akhter, \& Khan, 2011) bahwa "in the problem based learning approach the students' turn from passive listeners of information receivers to active, free self-learner and problem solvers". PBM merupakan sebuah pendekatan yang berpusat pada siswa dari pendengar penerima informasi pasif menjadi aktif, mengembangkan masalah dan keterampilan pemecahan masalah. Pendapat lain (Riski Tri Widyastuti \& Airlanda, 2021) bahwa pembelajaran berbasis masalah memiliki tujuan Membantu siswa mengembangkan keterampilan berpikir dan keterampilan pemecahan masalah. pembelajaran berbasis masalah melatih siswa untuk memiliki keterampilan berpikir tingkat tinggi. Hakikatnya kesukaran dan konteks dari keterampilan berpikir tingkat tinggi tidak dapat diajarkan menggunakan pendekatan yang dirancang untuk mengajarkan ide dan keterampilan yang lebih konkret, tetapi hanya dapat dilakukan dengan menggunakan pendekatan pemecahan masalah (problem solving) oleh siswa. Guru mendorong siswa untuk aktif berdiskusi dengan siswa, mendorong siswa untuk mempresentasikan penyelesaian masalah di depan kelas, dan mondorong memberikan pendapat apabila terdapat perbedaan jawaban LKSI/LKSK, hal ini sesuai dengan pendapat (Tambunan, 2019). Hal ini sesuai dengan pendapat Menurut (Arends, 2012) Karakter PBM mampu menghasilkan produk dan memamerkannya. Pembelajaran berbasis masalah menuntut siswa untuk menghasilkan produk tertentu dalam bentuk karya nyata dan peragaan yang menjelaskan atau mewakili bentuk penyelesaian masalah yang mereka temukan. Karya nyata dan peragaan direncanakan oleh siswa untuk mendemonstrasikan kepada teman-temannya yang lain tentang apa yang mereka pelajari.

Berdasarkan hasil temuan peneliti serta beberapa peneliti sebelumnya menunjukkan bahwa penerapan Pembelajaran berbasiswa masalah dapat meningkatkan motivasi dan self efficacy siswa sekolah dasar karena model PBL merupakan salah satu model pembelajaran yang merangsang partisipasi siswa secara aktif dan kreatif dalam menghadapi masalah kontekstual yang biasa terjadi dalam kehidupan sehari. Penelitian ini masih terdapat beberaapa keterbatasan seperti : kurangnya guru yang mampu mengelola kelas dengan menggunakan model pembelajaran berbasis masalah (PBL), tidak semua anak bersikap aktif dalam pembelajaran sehingga diperlukan usaha ekstra untuk membuat peserta didik aktif berpartisipasi dalam kelas , penerapan model Problem Based Learning (PBL) membutuhkan waktu yang cukup lama dalam pembelajaran karena peserta didik menggali sendiri konsep baru menggunakan pengetahuannya sendiri. Kehadiran guru dalam mendukung pembelajaran sangat diperlukan. 
2143 Peningkatkan Motivasi dan Self Efficacy Belajar Matematika melalui Model Pembelajaran Berbasis Masalah pada Siswa Sekolah Dasar - Dyah Anungrat Herzamzam

DOI: https://doi.org/10.31004/basicedu.v5i4.1177

\section{KESIMPULAN}

Berdasarkan hasil kegiatan pembelajaran yang telah dilakukan dalam dua siklus, dan berdasarkan seluruh pembahasan serta analisis yang telah dilakukan dapat disimpulkan sebagai berikut: (a)Pembelajaran berbasis masalah dapat meningkatkan motivasi siswa. Hal ini terlihat saat kondisi awal banyaknya siswa yang bergurau dengan teman sebangkunya, tidak memperhatikan guru saat pelajaran berlangsung, tidak mengerjakan tugas yang diberikan, pasif saat pelajaran berlangsung, banyaknya siswa melamun. Masalah tersebut disebabkan guru mengajar lebih banyak menggunakan metode ceramah. Meningkatnya motivasi dapat dilihat dari peningkatan skor motivasi siswa. (b) Pembelajaran berbasis masalah juga meningkatkan self efficacy. Hal ini terlihat saat kondisi awal siswa pasif dalam mengutarakan pendapat saat pelajaran berlangsung, siswa tidak bersedia mempresentasikan hasil jawaban di depan kelas, banyak siswa yang mencontek saat ulangan, siswa tidak yakin dengan jawaban mereka sendiri. Selain itu meningkatnya self efficacy siswa dapat dilihat dari sebagian besar siswa mampu memecahkan masalah yang diberikan oleh guru melalui alat peraga. Siswa tidak ragu dalam mengerjakan masalah bersama anggota kelompok. Siswa mampu berpikir secara mandiri menghadapi penyelesaian masalah matematika, siswa yakin pada penyelesaiannya dan berani memberikan pendapat terhadap perbedaan penyelesaian masalah. Siswa memiliki kemampuan dan keyakinan terhadap kebenaran konsep, prinsip prosedur matematika tentang masalah yang diselesaikan.

\section{UCAPAN TERIMA KASIH}

Penulis mengucapkan terimakasih kepada Kepala Sekolah dan Civitas Akademika SD N 5 Bumirejo Kebumen yang telah berkolaborasi pada seluruh rangkaian kegiatan penelitian. Selain itu kepada Ketua Prodi PGSD STKIP Kusuma Negara Bapak Chrisnaji Banindra Yudha, M.Pd yang selalu memberikan support dalam penulisan dan publikasi ilmiah.

\section{DAFTAR PUSTAKA}

Acuña, M. H., Ogilvie, K. W., Baker, D. N., Curtis, S. A., Fairfield, D. H., \& Mish, W. H. (2011). The Global Geospace Science Program and its investigations. In Space Science Reviews (Vol. 71). https://doi.org/10.1007/BF00751323

Ali, R., Hukamdad, D., Akhter, A., \& Khan, A. (2011). Effect of Using Problem Solving Method in Teaching Mathematics on the Achievement of Mathematics Students. Asian Social Science, 6(2), 67-72. https://doi.org/10.5539/ass.v6n2p67

Ambarningsih, D. (2014). Journal of Elementary Education. Peningkatan Hasil Belajar Menulis Puisi Bebas Melalui Metode Suggestopedia, 3(4), 14-20. Retrieved from http://journal.unnes.ac.id/sju/index.php/jee

Anik Handayani, \& Koeswanti, H. D. (2021). Meta-Analisis Model Pembelajaran Problem Based Learning (PBL) Untuk Meningkatkan Kemampuan Berpikir Kreatif. Jurnal Basicedu, 5(2), 1060-1066.

Areepattamannil, S., Freeman, J. G., \& Klinger, D. A. (2011). Intrinsic motivation, extrinsic motivation, and academic achievement among Indian adolescents in Canada and India. Social Psychology of Education, 14(3), 427-439. https://doi.org/10.1007/s11218-011-9155-1

Arends, R. I. (2012). LEARNING TO TEACH.

Dewi, S., Wiyasa, N., \& Suniasih. (2020). Pembelajaran Melalui Model Problem Based Learning Berbantuan Media Kartu Gambar Meningkatkan Kompetensi Pengetahuan Ipa Siswa. Journal for Lesson and Learning Studies, 3(2), 246-254. Retrieved from https://ejournal.undiksha.ac.id/index.php/JLLS/article/view/27276

Farozin, M., Yudha, C. B., Herzamzam, D. A., \& Mungad, M. (2019). The Educational Games Application Using Smartphone in Learning Mathematics for Elementary School Students. International Journal of Advanced Science and Technology, 122, 1-14. https://doi.org/10.33832/ijast.2019.122.01 
2144 Peningkatkan Motivasi dan Self Efficacy Belajar Matematika melalui Model Pembelajaran Berbasis Masalah pada Siswa Sekolah Dasar - Dyah Anungrat Herzamzam

DOI: https://doi.org/10.31004/basicedu.v5i4.1177

Flammer, A. (2018). Self-Efficacy. (April). https://doi.org/10.1016/B0-08-043076-7/01726-5

Froiland, J. M., Oros, E., Smith, L., \& Hirchert, T. (2012). Intrinsic Motivation to Learn: The Nexus between Psychological Health and Academic Success. Contemporary School Psychology, 16, 91-100.

Idrus L. (2019). Evaluasi Dalam Proses Pembelajaran. Manajemen Pendidikan Islam, 9(2), 920-935.

Kemmis, S., McTaggart, R., \& Nixon, R. (2014). The action research planner: Doing critical participatory action research. In The Action Research Planner: Doing Critical Participatory Action Research. https://doi.org/10.1007/978-981-4560-67-2

Mahadi, T. S. T., \& Jafari, S. M. (2012). Motivation, Its Types, and Its Impacts in Language Learning. International Journal of Business and Social Science, 3(24), 230-235. Retrieved from http://ijbssnet.com/journals/Vol_3_No_24_Special_Issue_December_2012/24.pdf

Mahmoud, A. A. A., \& Tanni, Z. A. (2014). Using Games to Promote Students' Motivation towards Learning English. Journal of Al-Quds Open University for Educational \& Psychological Research \& Studies, 2(5), 11-33. https://doi.org/10.12816/0016267

Rehman, A., \& Haider, K. (2013). The Impact of Motivation on Learning of Secondary School Students in karachi: An Analytical Study. Educational Research International, 2(2), 139-147.

Riski Tri Widyastuti, \& Airlanda, G. S. (2021). Efektivitas Model Problem Based Learning terhadap Kemampuan Pemecahan Masalah Matematika Siswa Sekolah Dasar. Jurnal Basicedu, 5(2), 1060-1066.

Santrock, J. W. (2012). Life Span Development (Thirteenth). New York,: McGraw-Hill.

Santrock, J. W. (2013). Educational Psychology (5th ed). New York,: McGraw-Hill.

Tambunan, H. (2019). The Effectiveness of the Problem Solving Strategy and the Scientific Approach to Students' Mathematical Capabilities in High Order Thinking Skills. International Electronic Journal of Mathematics Education, 14(2), 293-302. https://doi.org/10.29333/iejme/5715

Yudha, C. B. (2018a). Peningkatan Motivasi Belajar Mahasiswa pada Mata Kuliah Konsep Dasar Matematika Melalui Pendekatan Contextual Teaching and Learning. JPD: Jurnal Pendidikan Dasar, 12-27.

Yudha, C. B. (2018b). Peningkatan Self Efficacy Belajar Mahasiswa Menggunakan Model Pembelajaran Berbasis Masalah. Visipena, 9(1), 10-19. 